\title{
OPEN Author Correction: High-resolution multimodal photoacoustic microscopy and optical coherence tomography image-guided laser induced branch retinal vein occlusion in living rabbits
}

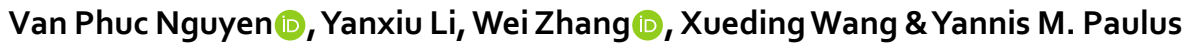

Correction to: Scientific Reports https://doi.org/10.1038/s41598-019-47062-2, published online 22 July 2019

This Article contains errors in the Results section where,

"It was noted that the vessel diameter of the untreated veins was (on average?) 132\% higher than that of the treated veins (vessel diameter $=121.88 \pm 7.18 \mu \mathrm{m}$ for untreated veins vs. $91.88 \pm 12.81 \mu \mathrm{m}$ for treated veins; $\mathrm{p}<0.05)$, indicating that the treated veins were thinner."

should read:

"It was noted that the vessel diameter of the untreated veins was $132 \%$ higher than that of the treated veins (vessel diameter $=121.88 \pm 7.18 \mu \mathrm{m}$ for untreated veins vs. $91.88 \pm 12.81 \mu \mathrm{m}$ for treated veins; $\mathrm{p}<0.05$ ), indicating that the treated veins were thinner."

"Additionally, the (average?) RNV vessel diameter was estimated to be $29.83 \pm 4.17 \mu \mathrm{m}$, which was $97.77 \%$ thinner than choroidal vessels $(59.00 \pm 11.47 \mu \mathrm{m}), \mathrm{p}<0.05$."

should read:

"Additionally, the RNV vessel diameter was estimated to be $29.83 \pm 4.17 \mu \mathrm{m}$, which was $97.77 \%$ thinner than choroidal vessels $(59.00 \pm 11.47 \mu \mathrm{m}), \mathrm{p}<0.05$."

(i) Open Access This article is licensed under a Creative Commons Attribution 4.0 International License, which permits use, sharing, adaptation, distribution and reproduction in any medium or format, as long as you give appropriate credit to the original author(s) and the source, provide a link to the Creative Commons license, and indicate if changes were made. The images or other third party material in this article are included in the article's Creative Commons license, unless indicated otherwise in a credit line to the material. If material is not included in the article's Creative Commons license and your intended use is not permitted by statutory regulation or exceeds the permitted use, you will need to obtain permission directly from the copyright holder. To view a copy of this license, visit http://creativecommons.org/licenses/by/4.0/.

(C) The Author(s) 2020 